\title{
6 \\ Moving to the country for a graduated retirement: constructing new meaningful lives
}

\author{
Lesley Hunt
}

\begin{abstract}
It is assumed that anything to do with 'the rural' is in decline but no account has been made of the flow of 'older' people into the countryside - those people who after successful careers elsewhere are moving to rural locations to set up new, supposedly less stressful working lives. In this chapter, I explore the way in which some couples in New Zealand are creating new and meaningful lives by growing kiwifruit, an activity that fits well with those who seek an active and graduated retirement.

These people saw orchards as actors capable of a moral exchange: 'if we make an orchard like this then it will reward us by giving us indications of our care'. Two different orchards were constructed. One was an orchard that was so wild that it needed to be made tidy and productive and the other was an orchard that was so needy it required nurturing. Are these 'new' orchardists really creating new lives or are they creating orchards that represent their old identities but in a different medium? What are the implications of their practices for the resilience of the environment, the countryside and the kiwifruit industry?
\end{abstract}

\section{Introduction}

We see a lot on television and in books (for example, Mayle 1992) about baby boomers starting a new life in the country, people, who, after stressful but successful professional careers in the city, are able to use their accumulated wealth to buy land. There they are, talking or writing enthusiastically about producing their own wine, olives, avocados or whatever, and about the merits of getting out of the rat race to live the idyllic life that the country provides. As one of the women in the research reported on here said: 'Other trees around - yeah, we've got persimmons, avocados, tamarillos, fejoas, guavas — bits and pieces. I like trees. I like space. I like the space. I love this. I've always wanted more than a quarter acre, so now I've got it' (Woman, organic). ${ }^{1}$ 
In New Zealand, it is not only wealthy people who have lived in the cities who are moving to more intensive, smaller landholdings. Some dairy farmers are doing it too as they escape from the early morning milking routine and being tied to the farm seven days of the week for much of the year. One of the popular options for ageing New Zealanders is to become a kiwifruit orchardist. In practice, the people I interviewed who had moved into kiwifruit after a career elsewhere were rather more 'ordinary' than those seen on TV and in books! Taking on a kiwifruit orchard could be as much of a risk as they are prepared to take, as earning a living is still important to them. They might not have amassed a lot of capital and might require a mortgage to start their new manner of living.

Growing kiwifruit is a way of life very suited to people who wish to move towards retirement in a graduated way:

[T] he vision for me, for my future? Spending the rest of my days here. I'm now sixty-two but I would see us staying in this home. We have no plan to move or downsize to a retirement village... and the beauty of orcharding is that you can do as much or as little as you choose...[With] us getting older, we are stepping back-like I've got contractors...[to] come in this winter and do two blocks of pruning for us. [My wife] won't be pruning anymore. She'll just do some of the tying down which is a lighter job and I'll continue to do the pruning while I can and then I would say a few years down the line, the contractors'll be doing more than what I'm doing, and if I'm not able to do too much at all I may just sit on the tractor and mow the orchard, and I might lease the orchard out to one of the packhouse facilities to run the orchard. So my business can continue to operate, I can oversee it. Probably I wouldn't be too popular with the lessees but-keep an eye on things and just step back. So it's a lifestyle that we're deliberately aiming for-yes. And being relatively mortgage free these days we can take that luxury I suppose and if there's [sic] downturns in the industry, we're not too exposed. (Man, organic)

As the orchardist above has described, the kiwifruit industry is well structured to support a lifestyle that involves as much work as a person is prepared to do, with it being possible to do the rest on contract, by leasing the orchard or handing its management over to someone else. This distinguishes these people from 'lifestylers' who wish to move to the country for its lifestyle while commuting to the city to earn their 'real' incomes. Kiwifruit grow well in locations that are very desirable places to live. They thrive in a temperate climate with cool winters and warm summers. In New Zealand, this means that the main growing areas are in the lush and beautiful Bay of Plenty, situated on the east coast of the North Island, close to stunning beaches. This contrasts with the iconic landscape of high country farming in Chapter 5 of this volume. The 
identities of those who grow kiwifruit, a symbolic New Zealand product, are associated with their landscapes in quite different ways from those of farmers as described by Carolyn Morris. Kiwifruit orchardists are able to create their landscapes whereas high country farmer identity is attached to the more 'natural' landscape of mountains.

Macnaghten and Urry (1998:4) have observed that "the "social" dimensions of nature have been significantly under-examined', and Shucksmith and Hermann (2002:39) advocate the importance of studying 'farmers' own ways of seeing the world'. Burton (2004:212) goes further, saying it is important to investigate farmers' behaviour when thinking about future change by taking greater account of social and cultural factors - especially identity and symbolic meaning. He is critical of quantitatively based research that finds attitudes but does not explore the real meaning behind the adoption or rejection of what are assumed to be friendly, environmental practices.

This chapter takes up the challenge posed by these writers to examine a largely unexamined phenomenon: the movement of older people into the horticultural industry. There is an increasing amount being written about the intensification of land use, biodiversity, sustainability and resilience, but no-one has thought about the values and motivations of this particular group and how they could impact on the countryside of the future. To do this, I draw together two strands of thinking to explain how these people, through their relationships with their orchards, construct identities of 'good' selves, living meaningful lives. They do this by conferring agency on non-human actors (orchards) and then developing a moral economy of exchange relationships with these non-human actors. This is not, however, the only dimension of this chapter. It also explains how relationships constructed in this way can determine the nature of production landscapes and the implications for the future of older people taking up rural lives.

A kiwifruit orchard can be seen as a rural space, 'lovingly cultivated and controlled nature' (Macnaghten and Urry 1998:179). It could be considered a 'careful and long-term construction of the tame, which includes domesticating and commodifying nature' (Buller 2004:132) in order to produce kiwifruit for the global market. How do kiwifruit orchardists relate to their orchards in order to do this and to make their lives meaningful? I observed an 'embedded and implicit' (Gray 1998:342) relationship between an orchardist and their orchard in the talk of orchardists about their practices. No particular theoretical positioning informed my gaze in this matter - that came later, as I grappled with making sense of what I was observing. 


\section{A moral economy of exchange between orchardists and their orchards}

\section{Agency and orchards}

At first, I was interested in orchardists' representations of a 'good' or ideal orchard as implied in their response to interview questions. I found that many described their orchard as pushing or encouraging them to interact with it in certain ways. Orchardists can develop an intimate relationship with their orchard-caring for it by mowing, pruning, controlling weeds, protecting it from frosts and fertilising the soil. These practices embed orchardists in the place of the orchard through the embodiment that arises from really doing something rather than gazing on it as an observer. As a result, the idea that an orchard could be thought of as an 'active' participant by orchardists evolved, just in the way that Jones and Cloke (2002) through the medium of ANT write about trees as actors in the landscape in their book Tree Cultures: The place of trees and trees in their place. They describe how practices to do with trees in different situations, such as on farms, in cemeteries and in orchards, have developed over time through relationships between people and trees.

\section{Social exchange}

Mauss (1990:83) makes the case that exchange relationships are a universal characteristic of any society: 'There is no other morality, nor any other form of economy, nor any other social practices save these.' Accordingly, there is no such thing as a free gift. A 'free' gift is one that supposedly does not entail a response from the recipient. As far as Mauss is concerned, however, any gift incorporates within it a moral implication of, a commitment to, a response of an equivalent nature: 'the unreciprocated gift makes the person who has accepted it inferior' (Mauss 1990:65). A gift is relational. It establishes a relationship and a commitment between the giver and the receiver (Douglas 1990:ix). There are no independent individuals, only social beings with connections (Douglas 1990:x).

Social exchanges do not operate just in the economic dimension. Exchange for work or goods is usually expressed in economic returns in our society, but exchange also operates in the legal, moral, religious, aesthetic and other domains (Mauss 1990:79). Therefore, orchardists who see themselves in an exchange relationship with their orchard are acknowledging their continuing commitment to their orchard: a continuing relationship of giving and receiving on the part of each. Every exchange can be assumed to have a moral dimension; there is an expected reciprocity. Although the relationship of orchard and orchardist encompasses a relationship with nature and with the land, it is not seen purely in those terms because the relationship is also an economic one: an orchard is a workplace (Clark and Lowe 1992). 
An orchard acts primarily as an enabler, an intermediary or a provider. In a manner similar to other forms of paid employment, orchardists are able to obtain what they want through their orchard: 'If I do this and this then the orchard will enable me to get this and this.' Hence, by responding to their orchard in a particular way, orchardists expect to get certain rewards.

\section{The nature of the rewards of exchange}

In Bourdieu's $(1998,1990)$ notion of capital in his theory of practice, a theory of social exchange (Bourdieu 1998:vii-viii), rewards can be viewed as capital of a symbolic nature through other people's recognition and acknowledgment of particular symbols that give people status in their eyes. Through their habitus, or 'disposition to act', people have learned from their life experiences the 'right thing to do' (Bourdieu 1998:8), thus habitus becomes embodied through the practices of everyday lives (Adams 2006:514-16; Lau 2004:374-6; Thompson 1992:12-17). Actions in the world are structured around fields that have particular rules that structure the game that must be played to increase or exchange capital. Capital comes in three basic forms-economic, social and cultural - and it is the cultural I wish to concentrate on. Cultural capital can be seen as having three components: the capital acquired through education, possession of 'things' that give status and the acquisition of qualities associated with habitus (Burton et al. 2008). The last two are of relevance here. The way in which an orchard is physically presented can provide status, but 'for a symbolic exchange to function, the two parties must have identical categories of perception and appreciation' (Bourdieu 1998:100). In other words, in order to comprehend what these physical aspects mean, orchardists must share a common understanding of the symbolic significance they have within the fields of the kiwifruit industry and the local and wider communities in which they live. I posit that alongside status, meaning could also be acquired as an orchardist's identity is reinforced and maintained.

\section{A moral economy}

Out of these insights emerged the realisation that what I was noticing was a 'moral economy' (Tanaka 2005; Robbins and Sharp 2003; Park et al. 2002). If an orchardist behaved in a particular way towards their orchard, they believed the orchard would not only reciprocate but was obliged to reciprocate because of the mutuality of exchange relationships. It would do this by producing a product that would enable the orchardist to have a livelihood and a lifestyle according to their hopes and expectations (apart from the constraints of the market).

Any action is usually associated with a moral judgment. Someone or some group is doing something that is considered good or bad from the perspective of some other person or group. As Matless (2001:522) has said, 'the conduct of particular groups or individuals in particular spaces may be judged appropriate or 
inappropriate, and the ways in which assumptions about the relationship between people and their environments may both reflect and produce moral judgments'. Many actions aim to make something 'better' than it was before, such as in assisting a plant to bear 'better' fruit or making the land 'better' by making it productive, as these orchardists in this study said:

[I]f I could leave them [farms/orchards/land] in a better condition than I found it then I was improving the land. And that didn't necessarily mean spraying the hell out of it. (Man, green)

We have to make things better. (Man, organic)

Obviously being organic we do more...than a lot of people towards the environment, and we're aware of it more. (Woman, organic)

I think it has made us more aware of the environment and looking after it, really. We're really only caretakers of it, you know, while we've got it, and the idea is that you leave it better than you found it. (Man, organic)

Some explanations for real farming practices are described in terms of the 'good farmer' or 'good farming' (Setten 2004; Burton 2004; Silvasti 2003). The particular model of concern to many is that of the 'productivist' approach to farming in which farm practices are oriented to producing more of a farm product such as meat or a crop rather than practices that care for the environment or produce so-called 'environmental goods'.

\section{The kiwifruit industry in New Zealand}

In New Zealand, the kiwifruit industry is dominated by ZESPRI, the single-desk marketer and exporter of New Zealand's kiwifruit. Rather than rewarding high productivity, the Taste Zespri program rewards high dry-matter fruit. It is very consumer focused. All export fruit from the more than 2000 kiwifruit growers has to meet the requirements of the GlobalGAP (formerly EurepGAP) audit system (in which GAP stands for good agricultural practices) and growers of organic fruit are certified by BioGro. To quote from the GlobalGAP web site (<www.globalgap.org $>$ ): 'The GlobalGAP standard is primarily designed to reassure consumers about how food is produced on the farm by minimising detrimental environmental impacts of farming operations, reducing the use of chemical inputs and ensuring a responsible approach to worker health and safety.'

GlobalGAP and BioGro carry out a process of certification of a product from farm inputs and all on-farm practices until it leaves the farm. Once certified, a farm is audited annually. 
To indicate the degree of the issue this chapter is describing, I provide here some of the relevant demographic details of kiwifruit orchardists in New Zealand. The average age of green orchardists was fifty-nine years, fifty-six for gold and fifty-eight for organic in 2006 (Fairweather et al. 2007:18); about 80 per cent lived on their orchard (Fairweather et al. 2007:18; Colmar Brunton 2007); 65 per cent were in households with no children; 72 per cent of orchards were owned and operated by the orchardist and his/her partner; and 83 per cent of orchardists were male (Colmar Brunton 2007). In 2006, 23 per cent said that they would be retired or have the orchard leased or managed within the next five years (Fairweather et al. 2007:21). All of these figures demonstrate the predominance of older orchardists in the kiwifruit industry.

\section{Method: the ARGOS program and this research}

This research has been carried out under the auspices of the Agricultural Research Group on Sustainability (ARGOS). It has a mandate from the Foundation for Research Science and Technology (FRST) ${ }^{2}$ to examine the environmental, social and economic sustainability of New Zealand farming systems through studies comparing organic systems with conventional (and sometimes integrated) systems in the kiwifruit, sheep/beef and dairying sectors (see <www.argos.org.nz $>$ ).

For the research program, I conducted interviews with 35 kiwifruit participants from May to November 2004. For the purposes of this chapter, however, only those orchardists who have come into orcharding after other careers and who live on their orchard have become subjects of interest. This whittles the number used as a resource for this work to six ZESPRI green, six certified organic green and three ZESPRI gold orchardists. Four of the green and two of the gold orchardists had been dairy farmers, while five of the organic orchardists had formerly lived and worked in towns or cities. The interviews consisted of semi-structured questions in which orchardists were asked about their visions for themselves and their orchard; what they thought would be possible indicators for the measurement of economic, environmental and social wellbeing; and what was going well and what was difficult for them in their management of the orchard (see Hunt et al. 2005). I also observed the orchards and have photographs of them.

The interviews were transcribed and the transcripts analysed using qualitative research methods (for example, Tolich and Davidson 1999) to understand what meaning orchardists gave to their lives in order for me as interviewer and researcher to 'abandon all previous judgements about what is objective, factual, natural or scientific, against what is subjective, historical, cultural or religious in order...to conceptualize the view...held by each farmer, not only as spoken in words, but also as interpreted in daily practice' (Kaltoft 1999:41). 
According to Morris (2004:281): 'A key contribution of ethnography to the study of processes often glossed as globalisation, is the attention such work pays to the micro-practices of the constitution and reproduction of identities in everyday life, for it is here that people work to achieve subjective stability.'

I will now outline the things that I found were important to the orchardists studied. This leads into a description of the sort of orchards that resulted from the expectations of the exchange between orchardists and their orchards.

\section{The importance of 'doing'}

It was 'unthinkable' (Bourdieu 1990:52-65) for these orchardists not to be 'doing' something for the rest of their lives. One green orchardist who used to be a dairy farmer said it was a 'lifestyle choice'. He and his wife used to work 'seven days a week for 23 odd years...we're both still working full-time. I can't see us ever...stop doing completely. You gotta retire to something you can't retire from - that's my belief anyway' (Man, green).

An exchange between an orchardist and myself on this subject went like this:

Interviewer: And when you say you like doing things, what do you mean by doing?

Orchardist: Well just mowing and repairing and...Well, just maintenance really. Instead of sitting around doing nothing, you've gotta do something. (Man, green)

A former teacher spoke of his desire for his future: 'It's lifestyle, it's wanting something that will carry us from teaching through to a productive retirement... and we don't imagine that we will retire and do nothing' (Man, gold).

Another spoke of his orchard in this way: 'It's an asset that can earn...a reasonable sort of income for us when we retire, and even perhaps...semi-retire, as I can't see myself staying here till sixty-five and stop working. I'll be needing to be doing something, and both physically and mentally' (Man, green).

An element of 'doing' is that it is an indication that these orchardists will still be working hard. They made comments about how their city friends had the idea that kiwifruit orcharding would provide a nice lifestyle in which the orchardist did very little and sat around sipping wine, but 'a relatively small block of land can mean an awful lot of work' (Man, gold). Another spoke of his first impressions and how wrong they were:

I'm an ex-engineer-[from] Auckland. I came down in '91 to visit my partner's father who's got [an] orchard down at Pangaroa. [I] [l]iked the place. And saw these old boys sitting on their backsides and all the fruit was growing and I thought, that's a good life. And they sucked me in 
nicely, didn't they? I haven't worked so many hours, for such a long time, in my life. (Man, organic)

\section{The rewards of doing}

These are orchardists who are serious about what they 'do'. It is not a 'game' or a hobby. They still feel that they have a need for income: 'You've got to have an interest...keeps you occupied...but at the end of the day it's what you get, the bottom line, the net figure' (Man, green). Or, as another person said, 'You've got to be realistic, you've got to make a dollar' (Woman, organic).

Other rewards come in the form of the symbolic capital gained from the appreciation of visitors to the orchard - and some of them are unexpected, as this orchardist described:

And I guess it's the response of people that visit. They come here and I don't want to be bragging in any way but people that come and visit the orchard, in their own way they are expressing the ambience of the place and if we get them sitting outside here, and it's just a nice atmosphere - even the tradespeople that we've had currently working on the house, the plumber and the pretty rough stone man that was in here, remarked how lovely it was and how nice and it was unusual to get that sort of response from people that I didn't think were sensitive to environmental type things. (Man, organic)

For some, the observation and protection of wildlife brings pleasure:

[I]n our four canopy hectares we'd have well in excess of a hundred birds' nests in the spring time out there. So we respect them, and we give way to them. If there's pruning to be done near the nest, well it doesn't get done... and in return we get the pleasure of seeing the chicks on the nest. (Man, organic)

For a couple (green), taking up a kiwifruit orchard was returning to a more carefree lifestyle. They called themselves 'recycled teenagers'. Another orchardist reflected on his working life: 'I've fished, I've trucked, I've owned a bar, and they're just nothing compared to this' (Man, green). The ex-teacher emphasises, not surprisingly perhaps, the fun of learning new things:

So, it's quite multi-skilled multi-tasked and, very interesting. Hell of a lot of fun...There's always the...financial side of things-you know-budgeting, record keeping, coming to terms with things like EurepGAP and...the Future Fed. certification we needed for selling in the local market, attending workshops and keeping up to date technically speaking, gaining qualifications for things like the Grow Safe qualification for doing your own spraying. And yeah, it's been a thoroughly enjoyable learning exercise - still is. (Man, gold) 
Another orchardist found growing organically a rewarding challenge:

I think there's a little bit of scepticism round the place [about being organic] - they were wondering how long it would be before we'd sort of bail out. That's probably still there a little bit but it's probably one of the things that makes me dig my toes in...Quite a few of us are proving that it can be done and it can be done economically...we've still got a long way to go but there's [sic] things that we're learning all the time-new products, new ways of doing things... Those of us that are in it now, I suppose you could say, are the pioneers of organics in kiwifruit growing, just because it is relatively new...it's always a challenge and just learning more and more about it. (Man, organic)

The orchard also provides a form of continuity, providing possibilities and meaning for the future and links to the past:

[O]ur vision really - because it's my wife's as well — is for it to be...able to provide a good lifestyle for us through into our retirement years. So it should provide money. It should also provide a healthy lifestyle. And we want to do that in the most ecologically friendly fashion we can, keeping in mind the demands of the markets for our fruit, and our own philosophies. (Man, gold)

I'm proud of this little place because it may not seem anything very spectacular to an outsider, but I know what it was eight years ago. So, it gives me, I suppose, a sense of satisfaction, to live here and be able to enjoy what I have done so far and plan what I'm going to do next. (Woman, green)

[T] he last two years we've been going up in crop... when you see that's happening you feel like you're doing, enjoying it-you know? And I enjoy doing something, so, yeah, the trays have gone from 14800 the first year; the second year we got 28 700; and this year-we haven't done a tally — but we should be around 34 this year. But we should be able to do 40. (Man, green)

\section{Linking the doing and the rewards}

There is an indication the reward from the orchard is in exchange for the 'doing' and that this is not just a monetary exchange. It is also an expectation of a moral exchange, a social contract between the orchard and the orchardist, as the two following quotes demonstrate:

[I]t's what you put into the orchard you get out type thing...I mean, you can go to orchards and you can tell that people don't do much on them because they're blinkin' terrible. And they've got terrible fruit. The 
pruners don't like them, the pickers don't like them, nobody likes working for them. (Man, green)

$[\mathrm{W}] \mathrm{e}^{\prime}$ ve worked really hard all our...working life so far...we have denied ourselves a lot to bring up a family and we'd like to think that OK, there will come a time when the income stream from the orchard will support a nice house, a good car, comfortable living conditions, a healthy work environment, and the opportunity to go overseas or have really good holidays. (Man, gold)

\section{The signifiers of the rewards of doing and caring}

There were two basic ways in which these orchardists saw their relationship with their orchard and these were signified by quite contrasting constructed landscapes. In the first landscape, the degree of care was demonstrated by how tidy the orchard looked, whereas for the second, care was demonstrated by the number of living things that were able to take refuge there. These orchards, however, were landscapes made through the particular way in which the orchardist thought of the agency of their orchard.

\section{The wild orchard: signified by tidiness and control}

The visual feedback provided by the 'look' of an orchard gave feedback to an orchardist that their management practices were correct. Tidiness was equated with orchard health, as the following two quotes indicate: ' $I$ 'd like to see the canopy...a pruned canopy....with nicely spaced canes...that certainly looks tidy.... good orchard looks healthy' (Man, green). And, 'I've got a vision that when it's all up and running, that all the shelter's nice and trimmed and it's even... being tidy is important to me... as well as...performing. And that's part of the health of the place, I believe' (Man, green).

Creating a tidy orchard brings with it the implication of the need for control: '[It] became a giant mess with different weeds and stuff getting in there, but it's reasonably tidy looking [now]....we keep it under control with the sheep' (Man, organic).

Unless the orchard is controlled, it will become wild and out of control. It will become recalcitrant and not do what an orchard 'should' do, which is produce lots of fruit. As one green orchardist said, 'There's [sic] a lot of young five year olds in there, which still need a bit of training.' Hence, I have called this a wild orchard because that is how the orchardist portrays its agency.

In this kind of orchard, the orchardists place an emphasis on production, making the land useful. This means that all available land is planted with kiwifruit vines, as this orchardist illustrates when he describes how they decided where to position their house: 'we needed a house...so we sort of plonked this one here. We've been here ever since [laughs]. But no, that's why we're...in the 
orchard - there's nowhere else you could put a house - unless we start cutting vines out and I didn't really wanna do that' (Man, green).

When I interviewed this man in his house and looked out the window, I found myself looking straight into the kiwifruit vines! For this next orchardist, by drawing on the knowledge he obtained from his experiences as a dairy farmer, he was able to totally reconstruct his orchard landscape by starting with a large amount of earth moving. As he explained to me while drawing a map of his orchard:

[I] did a lot of planning and drawing and whatnot from the dairy farm development work. This has all been contoured in here. That drain has actually been shifted... We brought it as close to the existing kiwifruit as we can. Eventually I'd like to tidy this area up and plant that out. No point in having that like it is. And some of the ground here we'll extend the canopy a wee bit on this row just to make use of the available space and tidy it up. (Man, green)

For another orchardist, his orchard was 'basically a wasteland' (Man, green) until he came along and made it useful.

The desire that orchardists have to keep their land 'neat and tidy' is not restricted to New Zealand, though it has been documented for farmers rather than those working in the horticultural sector. Others have drawn attention to this in England (Burton 2004; Burgess et al. 2000; McEachern 1992), the central plains of the United States (Nassauer 1997), Austria (Schmitzberger et al. 2005) and Finland (Silvasti 2003). As Burgess et al. (2000:121) express it, rough land is 'an anathema to farmers' sense of their professional identity and expertise'.

Beyond their practical application, these views contain a moral dimension: it is 'good' for an orchard to be helped to produce the best fruit it can, hence plants need to be guided, controlled or manipulated to produce, to be made better - more useful, more domestic - by controlling the fertility and growth of the vines and keeping the weeds and pests away so that all the available resources from the soil and plant will go into fruit production. It is good that every bit of available land is used to produce as much as possible.

The wild orchard that has become tidy fits all the descriptions of a 'good farmer'. The habitus of these orchardists is acted out on the orchard where a tidy, clean orchard signifies a good orchardist, the hard work that is needed to keep such a wild thing under control and in production and a person who cares about their orchard. Its tidiness, due to the weekly mowing and elimination of weeds, and its productivity are symbols that the orchardist is doing the 'right thing'; 'untamed and untended land represents decline and disarray' (Silvasti 2003:146). Tidiness is also a reflection of attitudes towards the land imbued from the days of New Zealand's colonisation, when land was broken in and control exercised 
over the 'wildness' (Egoz et al. 2001; Brooking 1996). It falls down, however, on one crucial point, which demonstrates how the moral economy approach enriches the understanding of orchards and orchardists. While paying attention to productivity, it is not necessarily the raison d'être for these orchardists. The reward they expect for attending to their orchard is a transition to a comfortable retirement lifestyle living alongside their orchard. As this process to a graduated retirement is worked through, often all an owner will do on their orchard is the mowing and weed control, hence these might be the only ways in which an orchardist can stamp their identity on the orchard. Regular mowing and weeding parallel the care that is taken of a garden. It is an example of an orchardist giving in to the 'urge to garden' (Brook 2003), creating a place where the orchardist feels 'at home'. A tidy orchard looks like a well-manicured garden: 'the economic as well as the aesthetic status of rural areas is generally predicated upon the exclusion of the wild' (Thomas 1983). This orchard is a demonstration of solidity and reliability and careful stewardship for one's future and of one's investment. 'This is a safe countryside where humanity nurtures and is, in return, nurtured by an accessible, appropriated and unthreateningly recognisable nature' (Buller 2004:132).

\section{The needy orchard: creating a haven}

The other kind of orchard is constructed by orchardists from their understanding of their orchards as needy - needing to be cared for, loved and nurtured-as the following quotes illustrate:

You can soon walk into an orchard and see if it looks stressed or anything like that...the colour of the leaves, the size of the leaves...same with any farm. You can work on a farm and soon tell whether it's lacking something or hungry. You might not know what [it is]. [If] you consistently produce...big crops and don't put the inputs in then eventually you're gonna have a reserve system...that you're gonna deplete. (Man, green)

Under the organic regime, we try and nurse the soil. (Man, organic)

Man: We do know that the high producing orchards are the ones that are run by the owners.

Woman: $[\mathrm{A}]$ nd they're out there every day, pruning and titivating.

Man: Doing it for love. (Organic)

In fact, these orchards did not look needy. The orchardists owning needy orchards responded to their orchards by creating a haven for as many living things as they could as long as these things did not threaten the orchard. 
I might mow here three times a year. I give the neighbour this side [a hard time]. He's just got a new mower and it's like a bowling green...got an hour to spare and he's out killing the place. But to me, the longer grass - there's [sic] creatures in it as well-bugs and birds and bits and pieces running round out there. (Man, organic)

[W] could see there are advantages to the neighbours in that...we don't have to worry about using aggressive chemicals near to where people live, and worry about what the wind is doing - that kind of thing...It's an organic orchard alongside them...I actually feel happier walking around this place than I do some other orchards... [In the] HiCane ${ }^{3}$ season the neighbours bring over their dog for walks...the neighbour on the other side quite often brings her horse for a walk and a bit of a chomp on the grass too...the neighbours have got 65 chooks [chickens]... which spend most of their time on our orchard. (Woman, organic)

This woman provided a refuge for her neighbour's hens, which had a practical side:

We have taken some from [the] neighbour as well, 'cause once they go off the lay a bit he just chops their head off. But we'll put them into the pension box over there... and we use the poo and I go down the orchard with a barrow load and just scatter it round the orchard-it's a little bit of nutrient for the plants as well. (Woman, organic)

The orchard was regarded as a haven that was an escape from suburbia. For example, one orchardist (Man, organic) criticised his neighbour for building a metal driveway the full length of his orchard. He said, 'That's bad-it's suburban...commercial industrialisation.' For some, this attitude extended to creating a less industrial space by making the orchard look like a garden:

Woman: The orchard's an extension of our garden...[at] the end of the rows and corners we've got various other shrubs and bits and pieces...just to make it look a bit sort of less clinical...it just breaks up the monocultures in there.

Man: And [it] keeps the bees in the [orchard all the time] and the bumble bees are lovely too - such gentle giants in the bee world and yeah-I haven't been stung by one yet.

Woman: Bumble bees work in the rain. (Organic)

The way in which all the things in the orchard worked together was expressed often, as in the quotes above and in the following. There is an essence that such orchardists are working with nature rather than seeking to control it. 
[In] October and November, the bees come in and do their bit. So in my case, four hectares, I have a million workers come on site and pollinate the crop. That's critical to getting both [the] size of kiwifruit and the yield as well. So the weather at that time is really important, the bees only fly in the good weather. And then we move into three months of summer pruning intensive work again, which I find quite enjoyable. And because of the nature of the canopy that we've organised for our convenience the vines start leafing up as the summer weather comes on, and working under the vines in the summertime, I say it's a large airconditioner, because the plants are transpiring moisture. Ah, they're taking the latent heat away from the canopy and underneath the canopy is actually cooler - not just because it's in the shade-but it's actually the latent heat is being extracted by the vines so we work in a wonderfully comfortable environment. The height's right - we don't have to reach unduly or bend over-it's designed at six feet and it's a good working environment there for us, so when the hot sun is out we've got the umbrella up. (Man, organic)

Overall, however, the orchard is performing a much higher purpose: by creating such a haven, the orchardist has contributed to making the world a better place: 'Oh it's just, I guess, being very satisfied [that] what we're doing is good for the world....and that we are not destroying the environment-we're actually contributing to it' (Man, organic).

The needy orchardist runs the risk of being called lazy by wild orchardists because for them tidiness implies hard work (Nassauer 1997; Burgess et al. 2000; Oresczyn and Land 2000; Egoz et al. 2001). Some 'needy' orchardists demonstrated an awareness of this risk by comparing themselves with wild orchardists. As Burton (2004:209) points out, however, 'an untidy farm is not necessarily an unprofitable farm... Therefore, "untidy" farmers may not be lazy farmers from an economic perspective'. Needy orchards are also viable businesses.

Thus, all orchardists described here have constructed orchards that represent their response to the agency they have attributed to their orchard and the care that they are taking of it. This care, however, is indicated in two different ways, resulting in tidy orchards and orchards that are teeming with life.

\section{Discussion and implications}

I now wish to examine what I have written thus far in two different ways: one rather more esoteric, the other pragmatic. First, I will consider the framework I have used: that of a constructed moral economy of exchange between two agents. How does this contribute to our understanding of how this group of people is constructing new and meaningful lives as kiwifruit orchardists making their way to retirement? Are they really forming new identities? Second, I will 
ponder the implications for the future of this movement of older people into rural life.

\section{Creating identity: living meaningful lives}

It is clear from the illustrations I have used that this group of people has come from an upbringing and life experience in which it is deeply ingrained that you do not get something for nothing and so it is important to be 'doing'. By implication, retirement, as in 'doing nothing of consequence', is not an option. This identity related to the work ethic becomes one of the values of the field of the communities in which these people live or have their friends, and has to be demonstrated by their orchard for themselves and other people to see. The orchard has to be a symbol of hard work and disciplined caring for the wild/tidy orchardists and of extravagant 'caring' and nurturance for the needy orchardist. There are, however, three moral issues also implied here. First, to be a good person one has to be working/doing, living a 'useful' life. Second, each orchardist in their own way is striving to make the orchard 'better'. For the wild orchardist, the orchard is better because it is under control, domesticated and no longer 'wild'; it is doing what an orchard should be doing: producing good fruit. For the needy orchardist, the orchard is no longer needy because the orchardist has fed it and made it into a haven where everything is welcome, creating an environment that not only produces wholesome fruit but is an example of care for the environment. Finally, there is reciprocity involved. If one 'does', there is the expectation of a return. As a reward for making it better, the orchard has to demonstrate its response to the actions of the orchardist. By attributing agency to their orchards, orchardists are able to accept as rightfully theirs the rewards the orchards produce because the rewards are in exchange for what they have done, thus reinforcing their identities as good people living meaningful lives. This could be very important to people on the way to retirement as they supposedly exchange an old identity maintained by work in another place and context to a new one. Otherwise, who would they be?

Are these people just creating a landscape like home (Brook 2003) and/or an identity that really is the same as it was in the past but just in a new setting? Bourdieu's theory of practice (1998) is usually seen as a theory of continuity (for example, Shucksmith and Hermann 2002; Setten 2004), but it can also help in the understanding of change (Raedeke et al. 2003:79) and identity (Adams 2006). Critics of Bourdieu consider his notion of habitus deterministic and restrictive (for example, Silber 2003), claiming that it limits an individual's capacity to act (Widick 2003:688; Jenkins 1992:77, 272). On the other hand, proponents of Bourdieu's approach argue that while habitus reduces possibilities for action through its deeply instilled ways of 'practising', many possibilities remain (Adams 2006:515). All of the orchardists in this study come from somewhere other than where they are now living. Therefore one has to ask how their past 
working experiences are affecting their expectations of and practices in their orchards. It is apparent that those in the ARGOS program taking up kiwifruit growing after experience in the primary sector in dairying are more likely to have a wild/tidy orchard than those from 'the city', who are more likely to have a needy orchard and are also more likely to take up organics. Ex-dairy farmers and some of the city folk might be happy to create an 'industrial' ordered environment - reflected by one of the quotes in which one person is rebelling against this concept. The kiwifruit is an exotic species - it has moved out of orchards to become classified by the Department of Conservation as a noxious weed - so it has an alien nature that people might wish to domesticate or keep suppressed and one way of doing so is to impose tidiness in a ruthless fashion. In contrast, those with urban backgrounds might be creating a less-ordered garden - for example, the same woman who is planting garden plants and shrubs in the kiwifruit orchard will encourage biodiversity but it will not look like a monoculture orchard, growing only kiwifruit.

There also appears to be a gender influence. I interviewed whoever chose to be interviewed, so in some instances there were couples and in others a single person, usually a male. Wherever there was a woman involved in the orchard work, she usually participated in the interview. Hence it seems more likely to be a couple involved in the needy orchard, whereas on the tidy orchard the woman is more likely to lead her own life and not participate in on-orchard work. Also, the emphasis placed on mowing the orchard is reflected in the literature. Some writers think there is an association between men and lawns, particularly between men and lawnmowers. In a book called The Grass is Greener: Our love affair with the lawn, Fort (2000) asserts that keeping a lawn 'right' is all about 'one-upmanship: how national pride, social status, even sexual identity can be bound up in the greenness and smoothness of the grass'. He shares the view that 'men love lawns because, like dogs, they repay love and attention' (Woolfrey 2000). One person he consulted thought the impulse to mow lawns 'sprang from a deeply imprinted desire to control and domesticate nature' (cited in Woolfrey 2000). The orchardists who are planning their retirement paths see mowing the grass in the orchard as the last thing they will give up. As stated earlier, this would then be the only way in which an orchardist could stamp their identity on the orchard.

What role does meeting the audit requirements of the GlobalGAP system play in the life of these orchardists? Tidy orchardists were more likely to complain about the book work associated with this. 'Doing' book work was not associated with on-orchard work, whereas the needy orchardists were more likely to accept the requirements - often already associated with BioGro if they were using organic practices - but they would complain about where this paperwork doubled up. (This has since been dealt with by making this information-providing process more streamlined with less redundancy.) Perhaps book work is more 
acceptable to people who formerly worked in offices. Meeting audit requirements is something that everyone in the kiwifruit industry has to do so it cannot be a distinguishing feature that differentiates one orchardist from another. Hence it is less likely to have much currency except in the way that it separates out New Zealand kiwifruit in the international marketplace, which can be a source of pride for all kiwifruit growers.

So, are these people changing their identities? I suggest that these people are using kiwifruit orcharding as a medium to maintain the continuity of their identity from past lives. For example, the teacher who values learning is still able to learn, and for all, the need to do something useful is still fulfilled. The orchard (and its economic return) provides further evidence and support for this identity. The orchard also provides a form of differentiation from other orchardists. In spite of the many constraints experienced by orchardists and the fact that they all grow a similar product, there are many ways in which their orchards can differ. In other words, the constraints of ZESPRI, meeting audit scheme requirements and meeting the expectations of neighbours and communities have not limited the choices of kiwifruit orchardists in the way they relate to their orchards and the influence of this on the orchard landscape.

\section{Issues for rural futures}

What are the implications of this movement of older people into the countryside, a place usually assumed to be the best for bringing up children? The demographic implications of countryside with an increasing proportion of older couples are intriguing. It raises questions about the impact of a very mobile, reasonably wealthy group of people on the local rural communities. I raise this as an issue for thought. I do not have any answers here except that it will obviously not do anything to increase the decline in the numbers of rural schools. Also, this is a group without long experience in orchards, therefore they will have greater needs for knowledge pertinent to this work. This leads nicely into the next issue.

Burton and Wilson (2006) have scrutinised the farming styles literature to develop themes which they say cover all the identified 'types'. They came up with four:

(1) 'Traditional' - a conservative productivist farmer who maintains cultural notions of stewardship; (2) 'Agribusiness person' - a farmer who concentrates on agricultural production to the extent that the profit motive dominates and stewardship concerns are lessened; (3) 'Conservationist' - a farmer who focuses on environmental and lifestyle concerns; and (4) 'Entrepreneur' - a farmer who is shifting the focus away from standard agriculture towards non-agricultural sources of income. (Burton and Wilson 2006:101)

It can be seen that the orchardists of a wild orchard are a mix of Burton and Wilson's first and second theme and the orchardists of needy orchards fit their 
conservationist theme. In other work, I have identified a challenging orchard whose orchardist is entrepreneurial and likes to take risks and try new things while staying within the orchard (see Hunt and Rosin 2007). This sort of orchardist, however, is not present in this study of 'older', 'new' orchardists and this could be a source of concern. Every industry needs its entrepreneurs - the people who try things out and introduce successful practices to the mainstream. They play an important part in the resilience of the system by introducing change and being prepared to try things even if they fail. In the future, the industry will need to make sure it continues to be attractive to such people. In the meantime, the needy orchardists add resilience to the kiwifruit industry by providing ways of growing kiwifruit without chemicals and with a greater care for environmental biodiversity, and the wild/tidy orchardists are guarantors of a steady and reliable supply of quality kiwifruit. As these people are new to the industry, however, and are ready to become more knowledgeable about it, when they learn they will be learning the latest practices. As the kiwifruit industry is renowned for how quickly it is able to change, this aspect will only enhance this ability, as long as it is not in conflict with the attributes of orchards and of themselves that this group values.

Maintaining a productive orchard requires periods of intensive seasonal labour. Winter pruning, which can be carried out over a longer period than summer pruning, is often able to be done by the owners. Summer pruning needs to be done quite quickly and more frequently and fruit picking requires only a day or two at the instant when the fruit is deemed to be ready. Contractors can do the spraying. Finding labour, especially skilled labour, is already a big issue in the horticultural industry and, as working orchardists such as those described here give up more and more manual work, this will be exacerbated, particularly as the New Zealand population ages. It also, however, provides a group of people who are likely to continue working after the age of 65 so there are pluses and minuses here.

\section{Conclusion}

Information such as that presented in this chapter could contribute to more resilient and sustainable orchard practices by developing a greater understanding that orchardists do not set out solely to gain materially, nor are all orchardists aiming for the same kind of orchard. Thus, this has demonstrated that the way in which an orchardist relates to their orchard is contested. As Setten (2004:391) states:

Notions of what is natural and unnatural are notions of morality, and notions of morality surface frequently because different people and groups know and conceive of landscape and nature in differing ways...The cultural meanings of nature shaped by individuals and groups are hence contested, because inherent in shaping the meanings of nature 
are powerful moral judgements as to who is 'right' or 'wrong', 'good' or 'bad', 'natural' or 'unnatural'.

This is a particularly interesting conclusion because for many forms of farming (for example, dairying; Jay 2005) only a single kind of productivist farm is rewarded with symbolic as well as economic capital. Jay indicates that such a farming structure reduces the chance of farmers taking up environmentally sustainable practices. If the land-use practices are to be sustainable and resilient there is a need for diverse models of potential practices so that choices are available to people. This poses less risk to the environment than a singular normative practice model. It also reveals for New Zealand, as in other places, the ways in which nature (as seen here in kiwifruit orchards) and 'social practices and values are inextricably interlinked and...[are] co-constitutive' (Buller 2004:139).

This chapter has explored how the people who have taken up kiwifruit growing as a progression to retirement adapt their orchard landscape so that things important to their identity in their former working lives are maintained. Such people contribute to the stability of the kiwifruit industry but will need to be balanced by the risk takers and supported by the encouragement of seasonal workers.

\section{Bibliography}

Adams, M. 2006, 'Hybridizing habitus and reflexivity: towards an understanding of contemporary identity?', Sociology, vol. 40, no. 3, pp. 511-27.

Bourdieu, P. 1990 [1980], The Logic of Practice, Polity Press, Cambridge, United Kingdom.

Bourdieu, P. 1998, Practical Reason: On the theory of action, Stanford University Press, Stanford, Calif.

Bourdieu, P. and Wacquant, L. 1992, An Invitation to Reflexive Sociology, Polity Press, Cambridge, United Kingdom.

Brook, I. 2003, 'Making here like there: place attachment, displacement and the urge to garden', Ethics, Place and Environment, vol. 6, no. 3, pp. 227-34.

Brooking, T. 1996, 'Use it or lose it: unravelling the land debate in late nineteenth-century New Zealand', New Zealand Journal of History, vol. 30, pp. 141-61.

Buell, L. 2001, Writing for an Endangered World: Literature, culture and environment in the US and beyond, Belknap Press at Harvard University Press, Cambridge, Mass.

Buller, H. 2004, 'Where the wild things are: the evolving iconography of rural fauna', Journal of Rural Studies, vol. 20, pp. 131-41. 
Burgess, J., Clark, J. and Harrison, C. M. 2000, 'Knowledges in action: an actor network analysis of a wetland agri-environment scheme', Ecological Economics, vol. 35, pp. 119-32.

Burton, R. J. F. 2004, 'Seeing through the "good farmer's" eyes: towards developing an understanding of the social symbolic value of "productivist" behaviour', Sociologia Ruralis, vol. 44, no. 2, pp. 195-215.

Burton, R. J. F. and Wilson, G. A. 2006, 'Injecting social psychology theory into conceptualisations of agricultural agency: towards a post-productivist farmer self-identity?', Journal of Rural Studies, vol. 22, pp. 95-115.

Burton, R. J. F., Kuczera, C. and Schwarz, G. 2008, 'Exploring farmers' cultural resistance to voluntary agri-environmental schemes', Sociologia Ruralis, vol. 48, no. 1, pp. 16-37.

Clark, J. and Lowe, P. 1992, 'Cleaning up agriculture: environment, technology and social science', Sociologia Ruralis, vol. 32, no. 1, pp. 11-29.

Colmar Brunton 2007, Understanding kiwifruit growers and their relationship with ZESPRI, Colmar Brunton Powerpoint presentation.

Douglas, M. 1990, 'Foreword: no free gifts', in M. Mauss, The Gift: The form and reason for exchange in archaic societies, W. W. Norton, New York and London, pp. vii-xviii.

Egoz, S., Bowring, J. and Perkins, H. C. 2001, 'Tastes in tension: form, function, and meaning in New Zealand's farmed landscapes', Landscape and Urban Planning, vol. 57, no. 3, pp. 177-96.

Fairweather, John, Hunt, Lesley, Cook, Andrew, Rosin, Chris, Benge, Jayson and Campbell, Hugh 2007, New Zealand farmer and grower attitude and opinion survey: kiwifruit sector, ARGOS Research Report 07/08, $<$ www.argos.org.nz>

Fort, T. 2000, The Grass is Greener: Our love affair with the lawn, Harper Collins, Glasgow.

Gray, J. 1998, 'Family farms in the Scottish Borders: a practical definition of hill farmers', Journal of Rural Studies, vol. 14, no. 3, pp. 241-356.

Hunt, L. and Rosin, C. 2007, 'The active kiwifruit orchard: orchard/orchardist interaction', ISHS Acta Horticulturae, vol. 753, <http://www.actahort.org/books/753/753_76.htm>

Hunt, L. M., Rosin, C., McLeod, C., Read, M., Fairweather, J. R. and Campbell, H. R. 2005, Understanding approaches to kiwifruit production in New Zealand: report on first qualitative interviews with ARGOS kiwifruit participants, ARGOS Research Report 05/01, July 2005, $<$ www.argos.org.nz> 
Jay, M. 2005, 'Remnants of the Waikato: native forest survival in a production landscape', New Zealand Geographer, vol. 61, pp. 14-28.

Jenkins, R. 1992, Pierre Bourdieu, Routledge, London.

Jones, O. and Cloke, P. J. 2002, Tree Cultures: The place of trees and trees in their place, Berg, Oxford.

Kaltoft, P. 1999, 'Values about nature in organic farming practice and knowledge', Sociologia Ruralis, vol. 39, no. 1, pp. 39-53.

Lau, R. W. K. 2004, 'Habitus and the practical logic of practice: an interpretation', Sociology, vol. 38, no. 2, pp. 369-87.

McEachern, C. 1992, 'Farmers and conservation: conflict and accommodation in farming politics', Journal of Rural Studies, vol. 8, no. 2, pp. 159-71.

Macnaghten, P. and Urry, J. 1998, Contested Natures, Sage Publications, London.

Matless, D. 2001, 'Moral geographies', in R. J. Johnston, D. Gregory, G. Pratt and M. Watts (eds), Dictionary of Human Geography, Fourth edition, Blackwell, Malden, Mass., p. 522.

Mauss, M. 1990, The Gift: The form and reason for exchange in archaic societies, Translated by W. D. Halls, W. W. Norton, New York and London.

Mayle, P. 1992, A Year in Provence, Ulverscroft, Leicester.

Morris, C. 2004, 'The Great Depression and the downturn: narrating continuity in the high country', New Zealand Sociology, vol. 19, no. 2, pp. 281-98.

Nassauer, J. 1997, 'Cultural sustainability: aligning aesthetics and sustainability', in J. Nassauer (ed.), Placing Nature: Culture and landscape ecology, Island Press, Washington, DC, pp. 67-83.

Oresczyn, S. and Land, A. 2000, 'The meaning of hedgerows in the English landscape: different stakeholders' perspectives and the implications for future hedge management', Journal of Environmental Management, vol. 60, pp. 101-18.

Park, J., Scott, K., Cocklin, C. and Davis, P. 2002, 'The moral life of trees: pastoral farming and production forestry in northern New Zealand', Journal of Anthropological Research, vol. 58, pp. 521-44.

Raedeke, A. H., Green, J., Hodge, S. and Valdivia, C. 2003, ‘Farmers, the practice of farming and the future of agroforestry: an application of Bourdieu's concepts of field and habitus', Rural Sociology, vol. 68, no. 1, pp. 64-86.

Robbins, P. and Sharp, J. T. 2003, 'Producing and consuming chemicals: the moral economy of the American lawn', Economic Geography, vol. 79, no. 4, pp. 425-51. 
Schmitzberger, I., Wrbka, T., Steurer, B., Aschenbrenner, G., Peterseil, J. and Zechmeister, H. G. 2005, 'How farming styles influence biodiversity maintenance in Austrian agricultural landscapes', Agriculture, Ecosystems and Environment, vol. 108, pp. 274-90.

Setten, G. 2004, 'The habitus, the rule and the moral landscape', Cultural Geographies, vol. 11, pp. 389-415.

Shucksmith, M. and Hermann, V. 2002, 'Future changes in British agriculture: projecting divergent farm household behaviour', Journal of Agricultural Economics, vol. 53, pp. 37-50.

Silber, I. F. 2003, 'Pragmatic sociology as cultural sociology. Beyond repertoire theory?', European Journal of Social Theory, vol. 6, no. 4, pp. 427-49.

Silvasti, T. 2003, "The cultural model of "the good farmer" and the environmental question in Finland', Agriculture and Human Values, vol. 20, pp. 143-50.

Tanaka, K. 2005, 'Redefining the moral responsibilities for food safety: the case of red meat in New Zealand', Rural Sociology, vol. 70, no. 4, pp. 470-90.

Thomas, K. 1983, Man and the Natural World, Allen Lane, London.

Thompson, J. B. 1992, 'Editor's introduction', in P. Bourdieu, Language and Symbolic Power, Polity Press, Cambridge, pp. 1-31.

Tolich, M. and Davidson, C. 1999, Starting Fieldwork: An introduction to qualitative research in New Zealand, Oxford University Press, Melbourne, Australia.

Widick, R. 2003, 'Flesh and the free market (on taking Bourdieu to the options exchange)', Theory and Society, vol. 32, nos 5-6, pp. 679-723.

Woolfrey, Celia 2000, 'One man went to mow', The Guardian, 16 September 2000, viewed 21 October 2008,

<http://www.guardian.co.uk/books/2000/sep/16/houseandgarden.features>

\section{Endnotes}

1 These are quotes taken from interviews with orchardists as described later in the 'method' section. Eighty-six per cent of kiwifruit orchardists grow the green-fleshed Hayward variety of kiwifruit, 21 per cent grow the gold-fleshed variety and 5 per cent grow fruit organically (Colmar Brunton 2007). (These figures do not add to 100 per cent because some orchardists grow gold and green kiwifruit.) Hereafter, the orchardists will be referred to as green, organic and gold.

2 The government organisation assigned the task of allocating funding to research that meets government goals.

3 A bud break spray. 